\title{
Indoor air quality in a restaurant kitchen using margarine for deep-frying
}

\author{
Sait C. Sofuoglu ${ }^{1,2} \cdot$ Melis Toprak $^{3} \cdot$ Fikret Inal $^{1}$ • \\ Arif H. Cimrin ${ }^{4}$
}

Received: 27 February 2015 / Accepted: 19 May 2015 /Published online: 29 May 2015

(C) Springer-Verlag Berlin Heidelberg 2015

\begin{abstract}
Indoor air quality has a great impact on human health. Cooking, in particular frying, is one of the most important sources of indoor air pollution. Indoor air $\mathrm{CO}, \mathrm{CO}_{2}$, particulate matter (PM), and volatile organic compound (VOC) concentrations, including aldehydes, were measured in the kitchen of a small establishment where a special deepfrying margarine was used. The objective was to assess occupational exposure concentrations for cooks of such restaurants. While individual VOC and $\mathrm{PM}_{2.5}$ concentrations were measured before, during, and after frying events using active sampling, TVOC, $\mathrm{PM}_{10}, \mathrm{CO}, \mathrm{CO}_{2}$, temperature, and relative humidity were continuously monitored through the whole period. VOC and aldehyde concentrations did not increase to considerable levels with deep-frying compared to the background and public indoor environment levels, whereas $\mathrm{PM}_{10}$ increased significantly ( 1.85 to 6.6 folds). The average $\mathrm{PM}_{2.5}$ concentration of the whole period ranged between 76 and $249 \mu \mathrm{g} / \mathrm{m}^{3}$. Hence, considerable PM exposures could occur
\end{abstract}

Responsible editor: Constantini Samara

Electronic supplementary material The online version of this article (doi:10.1007/s11356-015-4762-6) contains supplementary material, which is available to authorized users.

Sait C. Sofuoglu

cemilsofuoglu@iyte.edu.tr; saitcemil@iit.edu

1 Department of Chemical Engineering, Izmir Institute of Technology, Gulbahce, Urla 35430, Izmir, Turkey

2 Department of Environmental Engineering, Izmir Institute of Technology, Gulbahce, Urla 35430, Izmir, Turkey

3 Environmental Engineering Graduate Program, Izmir Institute of Technology, Gulbahce, Urla 35430, Izmir, Turkey

4 Faculty of Medicine, Department of Pulmonary Medicine, Dokuz Eylül University, Balçova 35340, İzmir, Turkey during deep-frying with the special margarine, which might be sufficiently high to cause health effects on cooks considering their chronic occupational exposures.

Keywords Indoor air quality $\cdot$ Restaurant $\cdot$ Kitchen · Deep-frying $\cdot$ Margarine

\section{Introduction}

Cooking is one the most important sources of indoor air pollution as it emits a wide range of potent pollutants that include aldehydes, volatile organic compounds (VOCs), particulate matter (PM), and polycyclic aromatic hydrocarbons (Abdullahi et al. 2013). Frying is the highest emitting type of cooking (Buonanno et al. 2011; He et al. 2004; Lee et al. 2001; See and Balasubramanian 2006; Svendsen et al. 2002) along with barbecuing/grilling (Lee et al. 2001; Taner et al. 2013). Specifically, deep-frying emits considerable amounts of pollutants, since the oil may be used for prolonged times of up to 9 days (Totani et al. 2006) deteriorating the quality of oil, and resulting in accelerated formation of oxidized and polymerized lipid species, and in turn, formation of volatile and non-volatile compounds (Wai 2007). It may take only 3 to 5 days for oil to reach $25 \%$ polar compounds content, which is the European Union limit level (Wai 2007). Dana and Saguy (2001) report in their review that the limit was exceeded in $35-60 \%$ of the oil samples collected from Western fast-food restaurants in five European countries. The major volatile constituents of used frying oils included hexanal, octanal, and nonanal (Takeoka et al. 1996). Emissions of frying include these aldehydes and others (e.g., acetaldehyde, acrolein, and formaldehyde), many VOCs (e.g., benzene, ethylbenzene, toluene, and xylene), and PM (Abdullahi et al. 2013; Kim et al. 2011). 
Fumes of frying at high temperatures have been classified as "probable human carcinogen" by the International Agency for Research on Cancer (IARC 2010). Lung cancer odds ratio has been reported to be higher for deep-frying (2.56) than for panfrying (1.47) and stir-frying (1.12) for Chinese nonsmoking women (Yu et al. 2006). Frying fumes have also irritating content such as aldehydes, aerosols, and VOCs (Svendsen et al. 2003), some of which are mutagenic substances (Sjaastad and Svendsen 2008). PM have been linked to pulmonary, cardiac, renal, and dermal toxic effects (Schwela 2000).

A variety of oils used for frying has been studied. Safflower oil was found to emit more aldehydes compared to extra virgin olive, canola, and coconut oils probably because of the differences in monounsaturated and polyunsaturated fatty acid and antioxidant contents (Katragadda et al. 2010). The mean PM concentration in the cook's breathing zone was about an order of magnitude higher when margarine was used to panfry beefsteak compared to that when using rapeseed, soybean, and olive oils (Sjaastad and Svendsen 2008). The reason may be the higher water content of the margarine (17\%) compared to that of the remaining oils $(<0.07 \%$ ) (Sjaastad and Svendsen 2008), and/or its higher unsaturated fatty acid content. Higher kitchen indoor air pollutant concentrations were measured in small local restaurants than those in hotel, hamburger chain, and a la carte restaurants (Svendsen et al. 2002).

Nowadays, a deep-frying vegetable margarine is used in small-scale businesses, fast-food restaurants, school canteens, etc. to deep-fry such foods as potatoes and patties of meat in Turkey. Frying margarines are generally sold in 18-L tin containers and classified by the sellers as frying oil for restaurants and cafes suitable for all consumer groups. The frying margarine used in the study establishment is made of palm oil that contain antioxidant and antifoaming agent (dimethylpolysiloxane) as an additive. There are probably a considerable number of cooks and staff who are exposed to fumes of deep-frying with this type of oil, which has not been studied yet. This study aimed to characterize typical indoor air quality in the kitchen of a smallscale establishment that uses the margarine for deep-frying. Concentrations of $\mathrm{CO}, \mathrm{CO}_{2}, \mathrm{PM}$, and VOCs, including aldehydes, were measured before, during, and after frying events.

\section{Material and methods}

\section{Site and survey description}

A university canteen that serves the school of architecture during the day was the study site. Frozen French cut potatoes, chicken nuggets and schnitzels, beef and chicken patties were fried in a deep-fryer filled with $3 \mathrm{~L}$ of the deep-frying margarine. The temperature of the fryer was set to $180^{\circ} \mathrm{C}$ for French fries, and to $160{ }^{\circ} \mathrm{C}$ for the remainder of the products. The kitchen was naturally ventilated, and there was not an exhaust hood in the kitchen. The kitchen windows were kept closed while its entrance door was kept open by the employees during the regular operating conditions. The door opens to the section where hot and cold drinks are served and sandwiches are made. This section is in the customers' hall separated only by a counter. The hall ( 8 by $12 \mathrm{~m}$ ) is mainly for students to spend their breaks, where smoking is not allowed.

The deep-frying oil used in the study kitchen is made of palm oil, and produced according to the following specifications. A minimum of $99.9 \%(w / w)$ oil, a maximum of $0.1 \%(w /$ $w$ ) moisture, $0.1 \%$ free fatty acids (as oleic acid), and $1.0 \mathrm{meq} /$ $\mathrm{kg}$ peroxide content, melting point of $19-25^{\circ} \mathrm{C}$, solid fat content of $5-8 \%$ at $20{ }^{\circ} \mathrm{C}$ and a maximum of $2.0 \%$ at $35^{\circ} \mathrm{C}$.

The indoor air quality (IAQ) survey was conducted in two campaigns. Campaign 1 (November 2012) was set to observe the regular working conditions of lunch service. This campaign consisted of 3 survey days. On a regular day, 1$1.25 \mathrm{~kg}$ of potatoes were fried. Campaign 2 (January 2013) was arranged to investigate the effect of the main fried food (potatoes) amount on IAQ, and to create conditions that could reflect busy establishments by increasing the amount of potatoes fried. The experiment was conducted during the semester break when students are away and business drops to a minimum so that we can control the amount of potatoes fried. This campaign also consisted of 3 survey days. The amount of potatoes fried was the regular amount $(1.25 \mathrm{~kg})$ on the first day. Then it was doubled and tripled on the second and third days, respectively. Each survey-day measurements were carried out between 1100 and $1500 \mathrm{~h}$. The period of 1100 to $1200 \mathrm{~h}$ was "before frying", which was sampled and monitored to determine the background concentration levels. Then, 1230 to $1330 \mathrm{~h}$ was "during frying" period, followed by "after frying" period of 1400 to $1500 \mathrm{~h}$. The 30-min intervals between the samples were dedicated to collection of the sampling tubes, re-calibration of the sampling pumps, and placement of the new sampling tubes. Monitoring device continued working during these intervals.

\section{Sampling and monitoring}

IAQ survey included collection of samples for VOCs, aldehydes, and $\mathrm{PM}_{2.5}$. In each survey day, three VOC and aldehyde samples were collected to investigate before-, during-, and after-frying events. $\mathrm{PM}_{2.5}$, on the other hand, was sampled for the whole 4-h period due to concerns that 1-h sampling would be short to collect sufficient material for weighing. In the meantime, total VOCs (TVOC), $\mathrm{PM}_{10}, \mathrm{CO}$, and $\mathrm{CO}_{2}$ were continuously monitored to investigate the variation patterns in the concentrations. Stationary sampling/monitoring strategy was preferred since measuring all variables simultaneously was not practically possible by personal sampling. Indoor air sampling and measurement equipments were placed 
approximately $1.5 \mathrm{~m}$ above the ground near (50 $\mathrm{cm}$ away) the deep-fryer.

US EPA Methods IP-1B and IP-6A (USEPA 1990) were applied to collect VOCs on Tenax TA in stainless steel thermal desorption tubes filled with $100 \mathrm{mg}$ sorbent (SKC 226-340), and aldehydes on DNPH-coated silica gel sorbent tubes that contain a 300-mg front sorbent section and a 150-mg backup sorbent section (SKC 226-119), respectively. The samples were drawn using SKC Air Check 2000 pumps through Tygon tubing, with a flow rate of $66.7 \mathrm{~mL} / \mathrm{min}$ for VOCs and $1000 \mathrm{~mL} / \mathrm{min}$ for aldehydes for $60 \mathrm{~min}$. The pumps were calibrated at the beginning of each sample using appropriate range Bios, Defender 510 calibrators. At the end of each sample, the flow rate was checked again. $\mathrm{PM}_{2.5}$ samples were collected on $37 \mathrm{~mm}$ glass fiber filters using a Harvard impactor connected to a sampling pump (SP 280E; Air Diagnostics and Engineering Inc.) with a $20-\mathrm{L} / \mathrm{min}$ flow rate for $4 \mathrm{~h}$. The filters were conditioned in a desiccator for at least $24 \mathrm{~h}$ prior to weighing on a precision-balance with a $10-\mu \mathrm{g}$ resolution (Sartorius CPA 225D) before and after sampling. The 3M Quest EVM-7 was used as the monitoring device in this study to simultaneously measure TVOC, $\mathrm{PM}_{10}, \mathrm{CO}, \mathrm{CO}_{2}$, temperature, and relative humidity $(\mathrm{RH})$. The monitoring device measured $\mathrm{PM}_{10}$ concentrations using a $90^{\circ}$ optical light-emitting photometer. TVOC concentrations were measured with a photo ionization detector (PID sensor) in parts per billion (ppb) units, whereas non-dispersive infrared sensor (NDIR) was used to measure $\mathrm{CO}_{2}$ and $\mathrm{CO}$ concentrations in ppm units. The 5-min average values of every 15 -s readings were recorded.

\section{Analytical methods}

Tenax TA sorbent sample tubes were analyzed by an automated short-path thermal desorption/cryofocusing system (UNITY; Markes International Limited) that sits on injector/septum area of a gas chromatography (GC) (Agilent 6890N) mass spectrometry (MS) (Agilent 5973Nms) system. Tenax TA tubes were conditioned for at least $30 \mathrm{~min}$ at $350{ }^{\circ} \mathrm{C}$ while passing at least $50 \mathrm{ml} / \mathrm{min}$ of helium as carrier gas before the first use. Sampled tubes were desorbed at $250{ }^{\circ} \mathrm{C}$ for $3 \mathrm{~min}$. The GC run was initiated based on a time delay which was $8 \mathrm{~min}$ after the start of thermal desorption. In this study, GC was equipped with a HP-VOC $(60 \mathrm{~m} \times 320 \mu \mathrm{m} \times 1.80 \mu \mathrm{m})$ column. The run time for GC analysis was $41.25 \mathrm{~min}$. The operating conditions of TD-GC-MS system are provided in Tables S1 and S2 in the Supporting Material (SM) along with chemical properties, target ions, qualifier ions, and retention times that were used to identify each analyte (Table S3).

For aldehydes, $6 \mathrm{~mL}$ of acetonitrile (Merck 1.00030; $99.9 \%$ ) was used as the solvent for extraction. The solvent was flowed through the sorbent cartridges by stainless steel gas tight syringes (Agilent Gas Tight Luer Lock Valve 5183-4552 and 4451). Three milliliter of eluted sample was collected in
$4 \mathrm{~mL}$ vials (National Scientific, Screw Caps with PTFE Septa, C4015-1). Before analysis, the sample was diluted with water (1/1), from which $20 \mu \mathrm{L}$ was injected for analysis. All target aldehydes in the sample were identified and quantified by comparison of their retention times and peak heights or peak areas with those of standard DNPH derivatives. The linear gradient program varied the mobile phase composition periodically. The following gradient program was found to be adequate to achieve this goal: after $20 \mu \mathrm{L}$ sample injection, linear gradient was stable at $70 \%$ acetonitrile/30\% water in $10 \mathrm{~min}$, linear gradient from 70-100\% acetonitrile/30-0\% water in $20 \mathrm{~min}$, reverse gradient from 100-70\% acetonitrile $/ 0-30 \%$ water in $2 \mathrm{~min}$, then hold at $70 \%$ acetonitrile for $3 \mathrm{~min}$ to be ready for next injection. Agilent 1100 Series High Performance Liquid Chromatography (HPLC) that has an ultraviolet visible absorption detector operated at $360 \mathrm{~nm}$ was used for determination of target aldehydes. Operating conditions of the HPLC system and the retention times of the target analytes are provided in the SM (Tables S4 and S5).

\section{Quality assurance/quality control}

Eight- and four-point calibration curves were constructed using 52 compound Japanese Indoor Air Standard Mix (Supelco, 4M7537-U) by spiking into the sampling tubes for GC-MS, and 15 compound aldehydes mix (Supelco, 4M7285-U) for HPLC analyses, respectively, all of which with $\mathrm{R}^{2}>0.99$. Forty eight of the 52 VOCs and 14 of 15 aldehydes could be quantified with the GC-MS and HPLC methods, respectively. Acrolein is a highly unstable aldehyde, and it is usually converted to a more stable compound for analysis, so it is difficult to analyze with direct methods (Fullana et al. 2004). Acrolein is not determined in this study because the method that we used for aldehyde sampling is considered to be inappropriate to investigate acrolein. Three field blanks were analyzed for VOCs and aldehydes. Among the aldehydes, the highest mean field blank levels belonged to formaldehyde, butyraldehyde, and acetaldehyde as $0.81,0.66$, and $0.37 \mu \mathrm{g} / \mathrm{m}^{3}$, respectively. The highest mean level VOCs in field blanks were hexane, nonanal, and decanal as $0.33,0.25$, and $0.07 \mu \mathrm{g} / \mathrm{m}^{3}$, respectively. Limit of detection (LOD) was calculated for each analyte as the mean plus three standard deviations using the field blanks. The LODs for the above-listed six compounds were calculated as $1.06,1.30,0.51,1.27,0.96$, and $0.49 \mu \mathrm{g} / \mathrm{m}^{3}$ for formaldehyde, butyraldehyde, acetaldehyde, hexane, nonanal, and decanal, respectively. Concentrations reported in this study were blank corrected. Duplicate samples $(n=3)$ were also collected. The percent difference between the duplicates were acceptable $(\leq 25 \%)$ for all of the target analytes except for two $(1,2,4,5$ tetramethylbenzene with $32.4 \%$ and 1,1,1-trichloroethane with $38.9 \%$; see Table S6). Three samples were collected with two sorbent tubes connected in series to determine if breakthrough occurs. Breakthrough (proportion of analyte 
concentration in the backup tube to the front tube) was $>5 \%$ for seven of the 61 analytes: nonanal $(12.2 \%)$, toluene $(14.4 \%)$, acetaldehyde (15.5\%), decanal (16.0\%), hexaldehyde $(17.7 \%)$, hexane $(17.8 \%)$, and acetone ( $>25 \%$, for which concentrations are not reported in this study). The difference between the start and end sampling flow rate of each sample was found to be $<5 \%$.

\section{Results}

\section{Indoor air quality under regular operating conditions-campaign 1}

Concentrations of individual VOCs, including aldehydes, are measured as 1-h average concentrations of before deep-frying events to determine background levels, and during and after deep-frying to determine its effect on the kitchen indoor air quality. The average background concentrations of the majority of the VOCs were $<3 \mu \mathrm{g} / \mathrm{m}^{3}$. Higher concentration VOCs were limonene $\left(37.4 \pm 30.4 \mu \mathrm{g} / \mathrm{m}^{3}\right)$, n-heptane $\left(23.6 \pm 9.4 \mu \mathrm{g} / \mathrm{m}^{3}\right)$, ethyl acetate $\left(20.0 \pm 10.3 \mu \mathrm{g} / \mathrm{m}^{3}\right)$, nonanal $\left(13.7 \pm 1.6 \mu \mathrm{g} / \mathrm{m}^{3}\right)$, benzene $\left(5.7 \pm 4.0 \mu \mathrm{g} / \mathrm{m}^{3}\right)$, n-octane $\left(5.2 \pm 1.7 \mu \mathrm{g} / \mathrm{m}^{3}\right)$, and toluene $\left(4.2 \pm 0.6 \mu \mathrm{g} / \mathrm{m}^{3}\right)$. The average background concentrations of all aldehydes except for acetaldehyde and formaldehyde were $<1.0 \mu \mathrm{g} / \mathrm{m}^{3}$. The mean concentrations of these two compounds were $6.6 \pm 2.0$ and $2.7 \pm 0.3 \mu \mathrm{g} / \mathrm{m}^{3}$, respectively. The average background concentrations of the monitored pollutants, i.e., $\mathrm{PM}_{10}$, TVOC, $\mathrm{CO}$, and $\mathrm{CO}_{2}$ are reported as 5-min averages. The mean concentrations of the before-frying period were $498 \mu \mathrm{g} / \mathrm{m}^{3}, 15.1 \mathrm{ppb}, 2.45 \mathrm{ppm}$, and $566 \mathrm{ppm}$, respectively.

Five of the seven VOCs specified above had an increase in their concentrations during frying. These were $n$-heptane, eth$\mathrm{yl}$ acetate, nonanal, n-octane, and toluene. Their average concentrations were increased to $83.0,24.9,23.4,16.6$, and $4.4 \mu \mathrm{g} / \mathrm{m}^{3}$, respectively (Fig. 1). The highest increases were in n-heptane, n-octane, and nonanal as 3.5, 3.2, and 1.7 folds, respectively. Decanal, n-decane, and hexane were the compounds with average concentrations of $<5 \mu \mathrm{g} / \mathrm{m}^{3}$ in the background that increased during frying. Their average concentrations were increased by $1.35,1.54$, and 1.38 folds. Figure 1a shows the VOCs with the highest ( $\geq 1.25$ folds) increases. The concentrations were decreased in the after-frying period, but did not drop back to the background levels in $1.5 \mathrm{~h}$.

Out of aldehydes that were $<1.0 \mu \mathrm{g} / \mathrm{m}^{3}$, only hexaldehyde was increased to $\mathrm{a}>1-\mu \mathrm{g} / \mathrm{m}^{3}$ concentration during frying (from
Fig. 1 Compounds with the highest increasing concentrations during frying from the background levels in campaign 1 . a Three-day average concentrations (error bars show one standard deviation) and $\mathbf{b}$ daily concentrations ( $D$ day, $B F$ before frying, $D F$ during frying, $A F$ after frying)

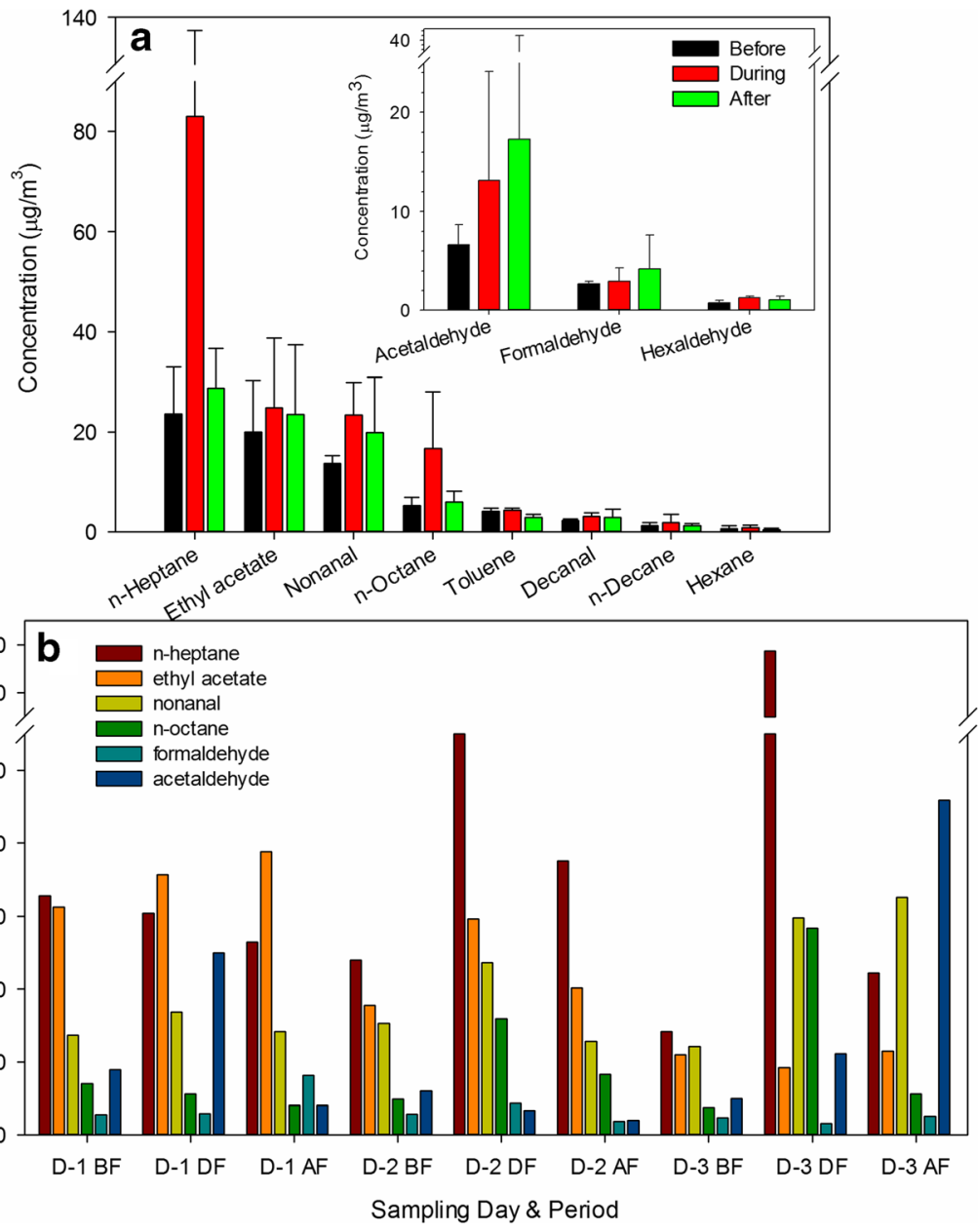


$0.78 \mu \mathrm{g} / \mathrm{m}^{3}$ before frying to $1.29 \mu \mathrm{g} / \mathrm{m}^{3}, 1.7$ folds). The highest increase was observed with 2.0 folds in acetaldehyde to $13.1 \mu \mathrm{g} / \mathrm{m}^{3}$, while formaldehyde was increased by only 1.1 folds to $2.95 \mu \mathrm{g} / \mathrm{m}^{3}$. In contrast to the VOCs, the average concentration of the two highest concentrations of aldehydes continued to increase in the after-frying period (Fig. 1a).

Although evaluation of the 3-day average concentrations yields varying levels of increases for the 11 compounds shown in Fig. 1a, there were instances where the concentrations did not increase during frying when the evaluation is made on the daily basis (n-heptane and n-octane on day-1, acetaldehyde on day-2, ethyl acetate and formaldehyde on day-3; see Fig. 1b).

A sample that integrated the three periods was collected for 4 hours daily to determine $\mathrm{PM}_{2.5}$ concentration which ranged from 76 to $158 \mu \mathrm{g} / \mathrm{m}^{3}$ with an average $( \pm \mathrm{SD})$ and a median value of $108( \pm 44)$ and $90 \mu \mathrm{g} / \mathrm{m}^{3}$, respectively. $\mathrm{PM}_{10}$ concentrations were, however, continuously measured from the very beginning to the end of every $15 \mathrm{~s}$ using a monitoring device. Then, 5-min averages of the measured concentrations were calculated. At the beginning of the monitoring, the average concentration of the 3 days was $316 \mu \mathrm{g} / \mathrm{m}^{3}$. However, probably due to activity in the room and/or early customer orders in 1 of the 3 days, the average of the before-frying period was $641 \mu \mathrm{g} / \mathrm{m}^{3}$. The 3-day average peak concentration in the during-frying period was $1583 \mu \mathrm{g} / \mathrm{m}^{3}$, whereas the average concentration of the whole period was $1192 \mu \mathrm{g} / \mathrm{m}^{3}$. $\mathrm{PM}_{10}$ concentrations were decreased in the after-frying period to an average of $471 \mu \mathrm{g} / \mathrm{m}^{3}$, while the concentration at the end was $279 \mu \mathrm{g} / \mathrm{m}^{3}$. This level was the result of concentrations measured in the first day. If only the other 2 days were considered, the period average and the end concentrations were calculated as 686 and $396 \mu \mathrm{g} / \mathrm{m}^{3}$, respectively. In conclusion, $\mathrm{PM}_{10}$ concentrations were considerably increased due to frying activity (by 4.75 and 1.85 folds if concentrations of beginning and peak, and average concentrations of the two periods were considered). The 20-min moving averages of the 5-min average measured concentrations are presented to trim the fluctuations for a smoother illustration of the variation (Fig. 2a).
Fig. 2 The 20-min moving averages of the 5-min measured concentrations during campaign 1 . a $\mathrm{PM}_{10}$ and $\mathbf{b}$ TVOC

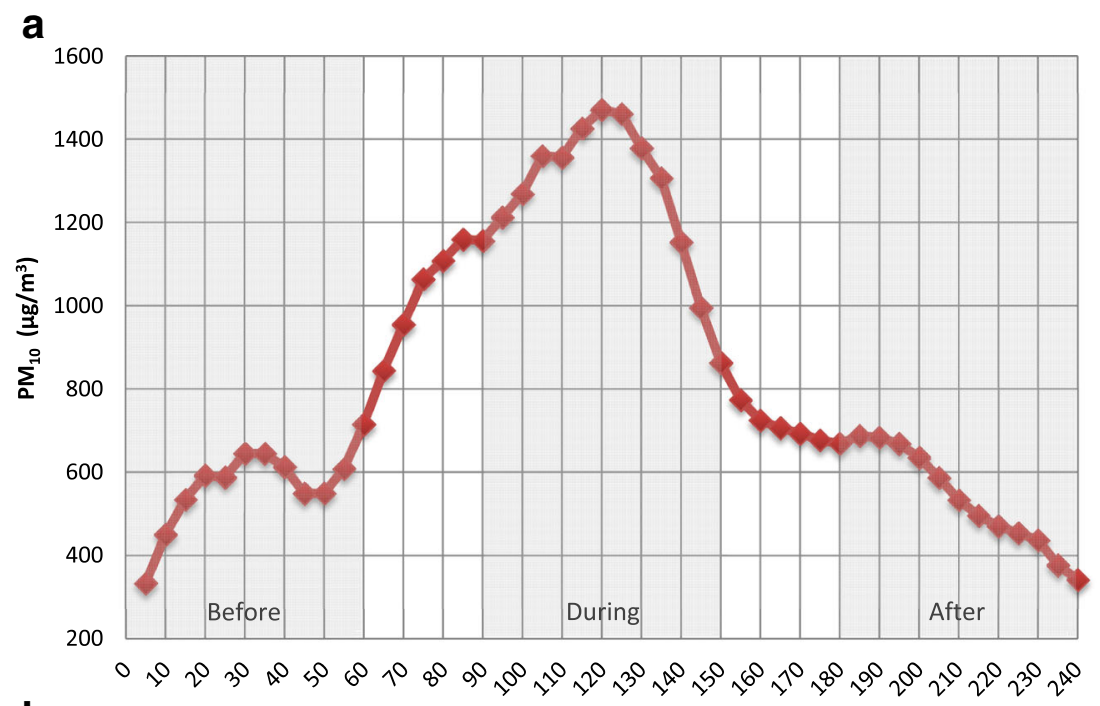

b

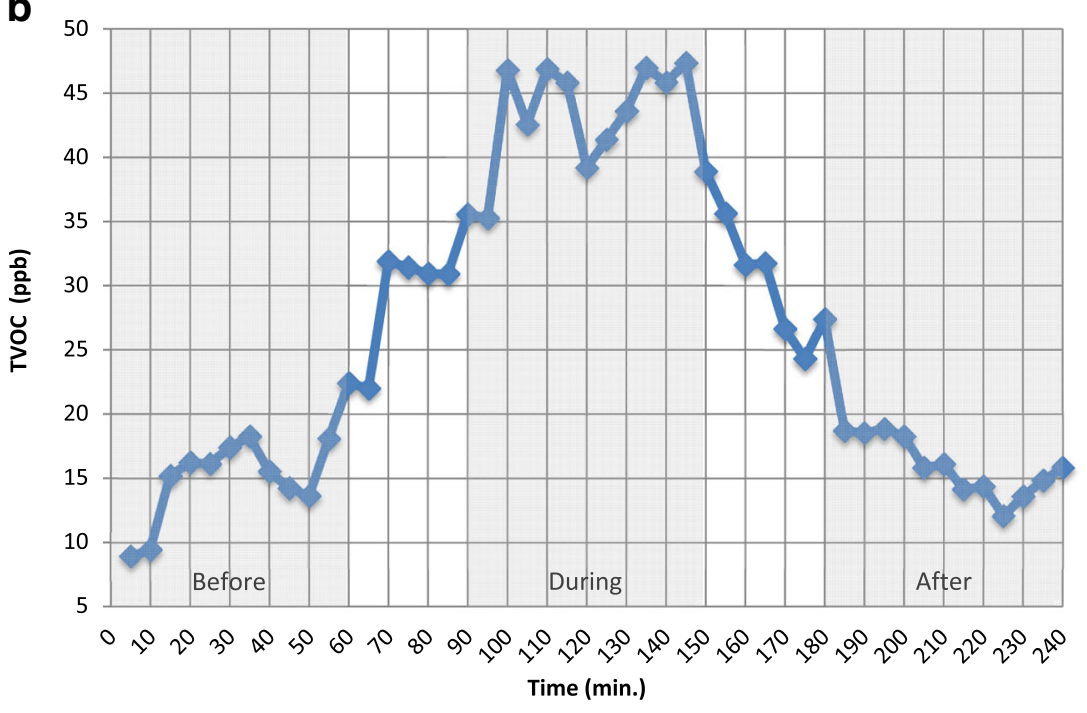




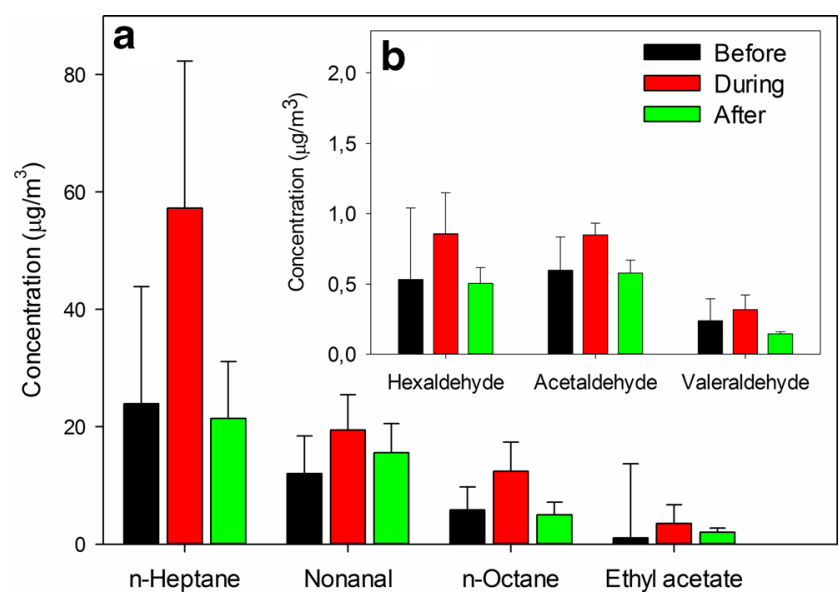

Fig. 3 Compounds with the highest increasing concentrations during frying from the background levels in campaign 2. a VOCs and b aldehydes (error bars show one standard deviation)

The average TVOC concentration was increased by 1.8 folds from before-frying period $\left(23 \mu \mathrm{g} / \mathrm{m}^{3}\right)$ to during-frying period $\left(40 \mu \mathrm{g} / \mathrm{m}^{3}\right)$, which then decreased to $15 \mu \mathrm{g} / \mathrm{m}^{3}$ in afterfrying period. The higher average concentration in the background was most probably due to the early customer order(s). In fact, concentration at the beginning $\left(12 \mu \mathrm{g} / \mathrm{m}^{3}\right)$ was lower than the one at the end $\left(15 \mu \mathrm{g} / \mathrm{m}^{3}\right)$. The increase due to frying was 4.5 folds when the beginning and the peak 5 -min average concentrations were considered. The 20-min moving averages of the 5-min average measured concentrations are also presented for TVOC (Fig. 2b).

$\mathrm{CO}_{2}$ concentrations did not increase with frying, whereas $\mathrm{CO}$ concentrations increased both in the during-frying and the after-frying periods from background of 2.33 to 2.67 and $3.33 \mu \mathrm{g} / \mathrm{m}^{3}$, respectively. Meanwhile, temperature was increased from 23 to $27{ }^{\circ} \mathrm{C}$ in the during-frying and stayed at this level in the after-frying period, whereas RH was decreased from 51 to $43 \%$ in the during-frying and continued to decrease to $39 \%$ at the end of the after-frying period.

\section{Indoor air quality under controlled operating conditions-campaign 2}

Campaign 2 was arranged to investigate the effect of fried potatoes amount on IAQ, and to create conditions that could reflect busy establishments. The amount of potatoes fried was the regular amount $(1.25 \mathrm{~kg})$ on the first day, which was then doubled and tripled on the second and third days, respectively. Consistent with the prior campaign, all target VOCs were detected at least once, except for 2-butanone. Concentrations of 35 VOCs were increased during frying compared to the background levels. The number of compounds with increasing concentrations was 22 in the prior campaign, 17 of which are among the 35 compounds, including the four compounds that increased the most.
The highest increasing four VOCs were the same ones as in the prior campaign but with a different order: ethyl acetate (3.3 folds), n-heptane (2.4 folds), n-octane (2.1 folds), and nonanal (1.6 folds). Although the increase in ethyl acetate concentration was the highest, the levels were low (from an average of 1.1 to $3.5 \mu \mathrm{g} / \mathrm{m}^{3}$ ). For nonanal on the other hand, the increase was relatively low (similar to other increasing compounds) but the levels were relatively high (from 12.0 to $19.4 \mu \mathrm{g} / \mathrm{m}^{3}$ ), only second to n-heptane (from 23.9 to $57.3 \mu \mathrm{g} / \mathrm{m}^{3}$ ). The concentrations are shown in Fig. 3a. Concentrations of the remaining increasing VOCs were $<3 \mu \mathrm{g} / \mathrm{m}^{3}$. Concentrations of six aldehydes (hexaldehyde, acetaldehyde, valeraldehyde, butyraldehyde, benzaldehyde, 2,5-dimethylbenzaldehyde) were increased by 1.3 to 1.6 times compared to the background levels. However, the average concentrations of the duringfrying period were low $\left(<1 \mu \mathrm{g} / \mathrm{m}^{3}\right)$ for all. The highest increasing three compounds are shown in Fig. 3b. In general, both VOC and aldehyde concentrations were lower than the prior campaign, although the amount of potatoes were increased. The TVOC values measured by the monitoring device were in agreement with the results from individual compound sampling that the levels were lower than the prior campaign. This may have resulted due to frying of only potatoes in this experimental campaign. In campaign 1 , meat products were also ordered by the customers, whereas campaign 2 was conducted in the semester break when there are almost no customers. Type of fried food is one of the variables that determine the profile and rate of the emissions (Buonanno et al. 2009, 2011).

$\mathrm{PM}_{2.5}$ concentration of the 4-h period that integrated the three sampling periods of before, during, and after frying were determined to range from 81 to $249 \mu \mathrm{g} / \mathrm{m}^{3}$ with the mean and median values of 147 and $110 \mu \mathrm{g} / \mathrm{m}^{3}$, respectively. The average $\mathrm{PM}_{10}$ concentrations of the before-, during-, and afterfrying periods were 613,4037 , and $635 \mu \mathrm{g} / \mathrm{m}^{3}$, respectively. The increase in the average concentration was 6.6 folds. The 5 -min average concentrations were fairly stable in the beforefrying period compared to that of campaign 1 , since no frying was performed as there were no early orders (Fig. 4). Increases in the PM concentrations were in line with the amount of potatoes fried for the both of $\mathrm{PM}_{2.5}$ and $\mathrm{PM}_{10}$ (Fig. 5), when both the mean concentrations of the during-frying period and the during- and after-frying periods were considered.

Similar to campaign $1, \mathrm{CO}_{2}$ levels did not increase with frying; $\mathrm{CO}$ levels were low (generally $<1 \mathrm{ppm}$ ); the average temperature increased (from $21.2{ }^{\circ} \mathrm{C}$ at the beginning to $27.7^{\circ} \mathrm{C}$ at the peak), while RH decreased (from $52.4 \%$ at the beginning to $41.0 \%$ at the nadir) in campaign 2 .

\section{Discussion}

The target analytes of this study included a total of 48 VOCs. All compounds, except for 2-butanone, were detected in all 
Fig. $4 \mathrm{PM}_{10}$ concentrations measured in campaign 2

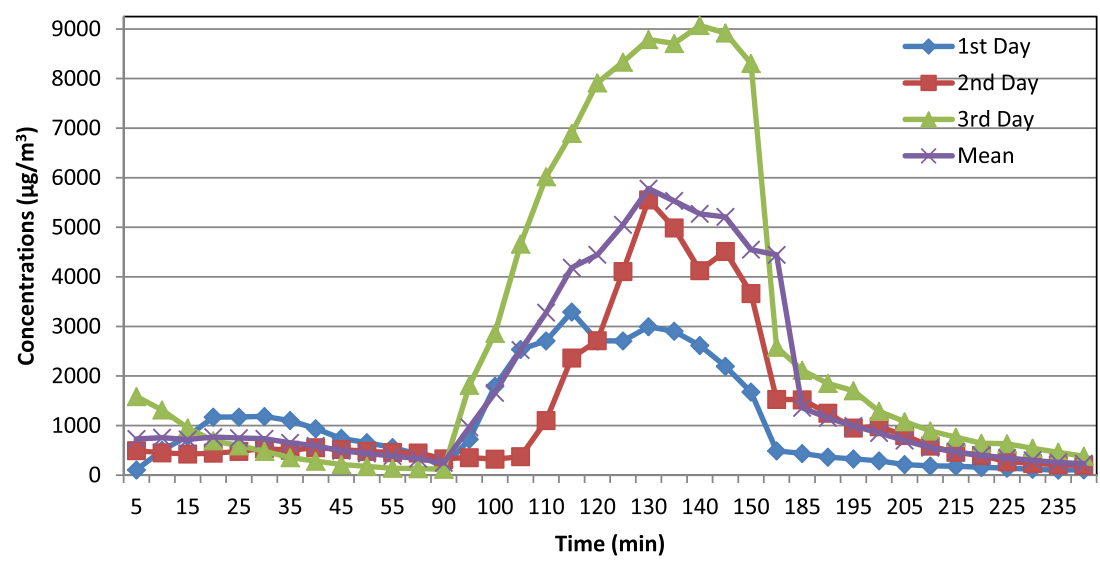

sampling periods in indoor air of the kitchen. The number of compounds with increasing concentrations during frying (i.e., 35) was higher in campaign 2 (controlled operating conditions: only potatoes were fried during off-season) than in campaign 1 (i.e., 22 in regular operating conditions). VOCs with the highest mean indoor concentrations $\left(>1 \mu \mathrm{g} / \mathrm{m}^{3}\right)$ were $\mathrm{n}$ heptane, ethyl acetate, nonanal, n-octane, toluene, decanal, and n-decane with 83.0, 24.9, 23.4, 16.6, 4.37, 3.12, and $1.91 \mu \mathrm{g} / \mathrm{m}^{3}$, respectively, in campaign 1 , whereas those were n-heptane, nonanal, n-octane, ethyl acetate, limonene, n-butanol, n-undecane, and n-dodecane with 57.3, 19.4, 12.4, 3.5, $1.57,1.27,1.13$, and $1.08 \mu \mathrm{g} / \mathrm{m}^{3}$, respectively, in campaign 2 . These differences point out that frying of meat products (hamburger patties, chicken patties, nuggets, and schnitzels) may affect both composition and levels of VOCs compared to frying only potatoes. The increased frying time due to increased amount of fried potatoes may also have contributed to the observed difference in the number of compounds with increasing concentrations of the two campaigns. The literature shows that type of food and time length of use for oil are among the variables that affect profile and quantity of emissions (Buonanno et al. 2009, 2011). The VOC concentrations measured in this study compare well with those reported in home and restaurant kitchens in different countries (Huang et al. 2011; Kim et al. 2011).

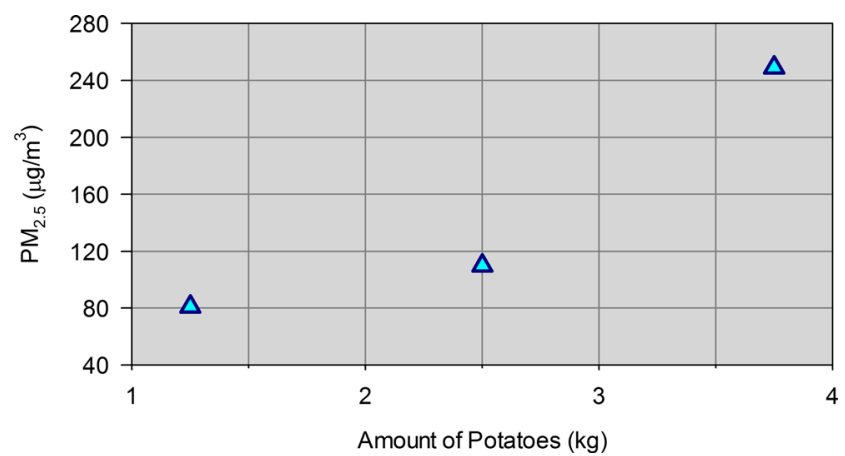

Fig. 5 Increase in $\mathrm{PM}_{2.5}$ concentration with increasing amount of potatoes fried
Three aldehydes, acetaldehyde, formaldehyde, and hexaldehyde with during-frying average concentrations of $13.1,2.95$, and $1.29 \mu \mathrm{g} / \mathrm{m}^{3}$, respectively, were the compounds with $>1 \mu \mathrm{g} / \mathrm{m}^{3}$ in campaign 1 , while none of the aldehydes were $>1 \mu \mathrm{g} / \mathrm{m}^{3}$ in campaign 2 . Two of the three compounds, hexaldehyde and acetaldehyde, were at levels higher $(>0.5 \mu \mathrm{g} /$ $\left.\mathrm{m}^{3}\right)$ than the others $\left(<0.35 \mu \mathrm{g} / \mathrm{m}^{3}\right)$. The measured concentrations of formaldehyde in this study are similar to those measured by Svendsen et al. (2002) in 19 restaurant kitchens mostly serving food fried with different vegetable oils. However, acetaldehyde concentrations measured in this study are much lower than those reported by Svendsen et al. (2002). Formaldehyde concentrations in the Korean barbecue style restaurants in Hong Kong were also much higher (Lee et al. 2001).

VOC and aldehyde levels were increased during frying, however, these concentrations were comparable to indoor air concentrations in other micro-environments such as primary school classrooms (Sofuoglu et al. 2011). PM concentrations, on the other hand, were increased during frying to considerably high levels for both $\mathrm{PM}_{2.5}$ and $\mathrm{PM}_{10}$. These levels were higher than those we previously measured (maximum concentration of $122 \mu \mathrm{g} / \mathrm{m}^{3}, 4-\mathrm{h}$ average) in a mosque and in university research laboratories (Ocak et al. 2012; Ugranli et al. 2015). The measured 4-h average $\mathrm{PM}_{2.5}$ concentrations (range $76-249 \mu \mathrm{g} / \mathrm{m}^{3}$ ) were within the range of those measured in homes and restaurants $\left(12-1406 \mu \mathrm{g} / \mathrm{m}^{3}\right)$ reported in a review by Abdullahi et al. (2013), but much lower than those measured in barbeque restaurants in Hong Kong with an average of $1167 \mu \mathrm{g} / \mathrm{m}^{3}$ (Lee et al. 2001), and Australian house kitchens with a median level of $745 \mu \mathrm{g} / \mathrm{m}^{3}$ (He et al. 2004). $\mathrm{PM}_{10}$ concentrations during frying were very high, with an average concentration of $1192 \mu \mathrm{g} / \mathrm{m}^{3}$ under the regular operating conditions, which was increased up to $6339 \mu \mathrm{g} / \mathrm{m}^{3}$ with increasing amount of potatoes in campaign 2 . These concentration levels are comparable to those previously reported (Abdullahi et al. 2013). Nevertheless, $\mathrm{PM}_{10}$ concentrations associated with frying are much higher than the indoor air standard level of $8-\mathrm{h}$ average $180 \mu \mathrm{g} / \mathrm{m}^{3}$ in Hong Kong 
(IAQMG 2003), but lower than the occupational standard of 8-h average $10,000 \mu \mathrm{g} / \mathrm{m}^{3}$ set by ACGIH (2001). The $\mathrm{PM}_{2.5}$ concentrations measured in this study are also higher than the indoor air guideline of $100 \mu \mathrm{g} / \mathrm{m}^{3}$ given by Health Canada (1995) but lower than the occupational standard of 8-h average $3000 \mu \mathrm{g} / \mathrm{m}^{3}$ set by ACGIH (2001). The measurements made by Fortmann et al. (2001) while deep-frying French fries in a test house kitchen have shown that PM concentrations in the breathing zone of the cook were four to six times higher than the indoor air of the kitchen for $\mathrm{PM}_{2.5}$, whereas $\mathrm{PM}_{10}$ concentrations were roughly as much higher in the room air than those in the breathing zone of the cook. Our measurements were not in the breathing zone, but they were not in the center of the kitchen either. Our samples were taken about $50 \mathrm{~cm}$ away from the deep-fryer at $1.5 \mathrm{~m}$ above ground. The literature shows that strong coagulation occurs resulting in larger particles from submicron ones (Abdullahi et al. 2013).

The increase in the concentrations from before- to duringfrying periods, and the decrease from during- to after-frying periods may be overestimations due to the 30-min gaps between the three sampling periods. However, the gaps seem to have not resulted in overestimations as the direction of increasing concentration trend does not shift considerably from before- to during-frying periods, and the direction of decreasing concentration trend in the after-frying period is not steeper than in the during-frying period appearing in Fig. 2, which shows the continuous monitoring measurements of $\mathrm{PM}_{10}$ and TVOC, during the gaps of the active sampling.

The average $\mathrm{CO}_{2}$ concentrations did not increase from before- to during-frying period in both of the campaigns. Furthermore, analysis of 5-min average concentrations measured in each of the 6 days to estimate variation within days showed that $\mathrm{CO}_{2}$ did not considerably vary in these two periods with coefficient of variation (CV) values of $<6 \%$ except for day 1 of campaign 2 (i.e., $15 \%$ ). $\mathrm{CV}$ was also calculated for $\mathrm{CO}_{2}$ concentrations of all 6 days to estimate variation between days as $14 \%$. Hence, it can be argued that, although it was not measured, air exchange rate did not have a major effect on the measured pollutant concentrations within or between days.

It should be noted that $\mathrm{PM}_{2.5}$ and $\mathrm{PM}_{10}$ were determined based on two different methods, gravimetric and online monitoring device, respectively. The online monitoring was employed as a support to the active sampling. In that sense, the monitoring device was used not to determine the exact concentrations, it was rather employed to be able to investigate the changes in the PM among background, during frying, and afterwards. It actually proved to be a useful tool as we could determine that although increases were observed in concentrations of all groups of pollutants during deep-frying, the increase and the levels of volatile organics were not as significant as for the PM.

The significance of aldehydes and PM has been shown in relation to malignant transformation in mammalian cells or inflammation markers (Bernstein et al. 2008; Sjaastad 2010). There are mutagenic and carcinogenic aldehydes ( $\mathrm{Li}$ et al. 1994; Wu and Yen 2004). In addition to their carcinogenic effects, VOCs may also induce mucous membrane irritation (Bernstein et al. 2008). Inhalation of acrolein and formaldehyde may result in local irritation in the respiratory tract (Ghilarducci and Tjeerdema 1995). Investigation of cultured human bronchial epithelial cells showed that exposure to dienaldehydes may induce oxidative stress, increased reactive oxygen species production, pro-inflammatory cytokines $\mathrm{TNF} \alpha$ and IL-1 $\beta$, and a decrease in GSH/GSSG ratio (glutathione status) (Chang et al. 2005).

\section{Conclusion}

Results of this study showed that considerably high levels of exposure to particulate matter could occur during deep-frying with the deep-frying margarine used in small-scale establishments. These levels might be sufficiently high to cause health effects on cooks considering their chronic occupational exposures.

Acknowledgments Partial financial support was provided by the Dokuz Eylul University Grant No. BAP-2011.KB.SAG.017. We thank the Environmental Research Center of Izmir Institute of Technology for the GC-MS analysis. We are grateful for the willingness and hospitality of the canteen owners Mr. Hüseyin Üçdağ, İbrahim Üçdăg, and Cuma Üçdağ.

\section{References}

Abdullahi KL, Delgado-Saborit JM, Harrison RM (2013) Emissions and indoor concentrations of particulate matter and its specific chemical components from cooking: a review. Atmos Environ 71:260-294

ACGIH (2001) Threshold limit values for chemical substances and physical agents and biological exposure indices. American Conference of Governmental Industrial Hygienists, Cincinnati

Bernstein JA, Alexis N, Bacchus H, Bernstein IL, Fritz P, Horner E, Li N, Mason S, Nel A, Oullette J, Reijula K, Reponen T, Seltzer J, Smith A, Tarlo SM (2008) The health effects of nonindustrial indoor air pollution. J Allergy Clin Immunol 121:585-591

Buonanno G, Morawska L, Stabile L (2009) Particle emission factors during cooking activities. Atmos Environ 43:3235-3242

Buonanno G, Johnson G, Morawska L, Stabile L (2011) Volatility characterization of cooking-generated aerosol particles. Aerosol Sci Technol 45:1069-1077

Chang LW, Lo WS, Lin P (2005) Trans, trans-2,4-decadienal, a product found in cooking oil fumes, induces cell proliferation and cytokine production due to reactive oxygen species in human bronchial epithelial cells. Toxicol Sci 87:337-343

Dana D, Saguy IS (2001) Frying of nutritious foods: obstacles and feasibility. Food Sci Technol Res 7:265-279

Fortmann RC, Kariher P, Clayton R (2001) Indoor air quality: residential cooking exposures final report (contract 97-330). Air Resources Board, State of California, Sacramento 
Fullana A, Carbonell-Barrachina AA, Sidhu S (2004) Comparison of volatile aldehydes present in the cooking fumes of extra virgin olive, olive, and canola oils. J Agric Food Chem 52:5207-5214

Ghilarducci DP, Tjeerdema RS (1995) Fate and effects of acrolein. Rev Environ Contam Toxicol 144:95-146

He CR, Morawska LD, Hitchins J, Gilbert D (2004) Contribution from indoor sources to particle number and mass concentrations in residential houses. Atmos Environ 38:3405-3415

Health Canada (1995) Exposure guidelines for residential indoor air quality: a report of the federal-provincial advisory committee on environmental and occupational health. Health Canada, Ottawa

Huang Y, Ho SSH, Ho KF, Lee SC, Yu JZ, Louie PKK (2011) Characteristics and health impacts of VOCs and carbonyls associated with residential cooking activities in Hong Kong. J Hazard Mater $186: 344-351$

IAQMG (2003) A guide on indoor air quality certification scheme for offices and public places. The Government of the Hong Kong Special Administrative Region, Indoor Air Quality Management Group, Hong Kong

IARC (2010) Household use of solid fuels and high-temperature frying. International Agency for Research on Cancer, Lyon

Katragadda HR, Fullana A, Sidhu S, Carbonell-Barrachina AA (2010) Emissions of volatile aldehydes from heated cooking oils. Food Chem 120:59-65

Kim KH, Pandey SK, Kabir E, Susaya J, Brown RJC (2011) The modern paradox of unregulated cooking activities and indoor air quality. J Hazard Mater 195:1-10

Lee SC, Li WM, Chan LY (2001) Indoor air quality at restaurants with different styles of cooking in metropolitan Hong Kong. Sci Total Environ 279:181-193

Li S, Pan D, Wang G (1994) Analysis of polycyclic aromatic hydrocarbons in cooking oil fumes. Arch Environ Health 49:119-122

Ocak Y, Kılıçvuran A, Eren AB, Sofuoglu A, Sofuoglu SC (2012) Exposure to particulate matter in a mosque. Atmos Environ 56: $169-176$

Schwela D (2000) Air pollution and health in urban areas. Rev Environ Health 15:13-42
See SW, Balasubramanian R (2006) Risk assessment of exposure to indoor aerosols associated with Chinese cooking. Environ Res 102: 197-204

Sjaastad AK (2010) Exposure to cooking fumes during the pan frying of beefsteak under domestic and occupational conditions. Norvegian University of Science and Technology, Trondheim, 228 pp

Sjaastad AK, Svendsen K (2008) Exposure to mutagenic aldehydes and particulate matter during panfrying of beefsteak with margarine, rapeseed oil, olive oil or soybean oil. Ann Occup Hyg 52:739-745

Sofuoglu SC, Aslan G, Inal F, Sofuoglu A (2011) An assessment of indoor air concentrations and health risks of volatile organic compounds in three primary schools. Int J Hyg Environ Health 214:38-46

Svendsen K, Jensen HN, Sivertsen I, Sjaastad K (2002) Exposure to cooking fumes in restaurant kitchens in Norway. Ann Occup Hyg 46:395-400

Svendsen K, Sjaastad AK, Sivertsen I (2003) Respiratory symptoms in kitchen workers. Am J Ind Med 43:436-439

Takeoka G, Perrino C, Buttery R (1996) Volatile constituents of used frying oils. J Agric Food Chem 44:654-660

Taner S, Pekey B, Pekey H (2013) Fine particulate matter in the indoor air of barbeque restaurants: elemental compositions, sources and health risks. Sci Total Environ 454:79-87

Totani N, Ohno C, Yamaguchi A (2006) Is the frying oil in deep-fried foods safe? J Oleo Sci 55:449-456

Ugranli T, Toprak M, Gursoy G, Cimrin AH, Sofuoglu SC (2015) Indoor environmental quality in chemistry and chemical engineering laboratories at Izmir Institute of Technology. Atmos Pollut Res 6:147-153

USEPA (1990) Compendium methods for the determination air pollutants in indoor air. US Environmental Protection Agency, Research Triangle Park

Wai T (2007) Local repeatedly used deep-frying oils are generally safe. Int J Sci Med Educ 1:55-60

Wu SC, Yen GC (2004) Effects of cooking oil fumes on the genotoxicity and oxidative stress in human lung carcinoma (A-549) cells. Toxicol in Vitro 18:571-580

Yu ITS, Chiu YL, Au JSK, Wong TW, Tang JL (2006) Dose-response relationship between cooking fumes exposures and lung cancer among Chinese nonsmoking women. Cancer Res 66:4961-4967 